\title{
Community Partnership Program (CPP/PKM) High School Teachers in Bandung City and District in E-Learning Based Data Collection Activities
}

\author{
Jusep Saputra $^{1 *}$, Thesa Kandaga ${ }^{2}$, Anggoro Ari Nurcahyo $^{3}$ \\ 1,2,3 Universitas Pasundan
}

\section{A R T I C L E I N F O}

Article history:

Received 20 December 2018

Received in revised form

1 January 2019

Accepted 30 January 2019

Available online 27

February 2019

Keywords:

Data processing, e-learning, video conference

\begin{abstract}
A B S T R A C T
The purpose of the Subject Teachers Consultation (STC/MGMP) will be if the teachers are skilled, accustomed and able to develop various activities that are able to support teacher competencies. One of the activities carried out was to participate in the Community Partnership Program (PKM) program development activities with LPTKs such as Pasundan University. The STC included in the Community Partnership Program (CPP/PKM) is the Bandung and City Mathematics STC. Problems with both partners are: (1) Some teachers do not know SPSS and its benefits in research, (2) Understanding of some teachers in collecting data according to the formulation of research problems is still lacking, (3) Some teachers do not know e-learning applications that use video conference. This problem has an impact on the inhibition of research and an increase in the rank of teachers. Approach methods used to overcome problems with training, mentoring, and mentoring. The two partners' solution-resolution procedures will be carried out by the team as follows: (1) Training, mentoring and mentoring in using SPSS features, (2) Training in using e-learning applications (3) Training, mentoring, and mentoring in collect data according to the formulation of research problems. CPP was attended by 14 Mathematics Teachers from the City of Bandung, and 17 Mathematics Teachers from Bandung Regency who were each from the Bandung City and Regency STC. The first meeting resulted in the following conclusions: (1) The quality of CPP in formulating problems, testing instruments, using SPSS features, and video conferencing conducted was very good, (2) The ability of teachers to understand, master, and train in making either test or nontest research instruments are in a pretty good category, (3) the teacher's ability to input data according to data or the scale of the data is in a good category, (4) The teacher's ability to use video conferencing to get guidance and assistance in doing the work is in good category.
\end{abstract}

\footnotetext{
* Corresponding author.

E-mail addresses: jusepsaputrapmat@unpas.ac.id (Jusep Saputra)
} 


\section{Introduction}

Subject Teachers' Consultation (MGMP), a non-structural organization under the Indonesian Government Regulation No.38 / 1994. According to the guidelines published by the Directorate General of Primary and Secondary Education, "MGMP has five objectives: (1) Encouraging teachers to improve their abilities and abilities plan, work and evaluate learning and teaching activities; (2) Containers to negotiate issues relating to the teacher in carrying out daily tasks and to find suitable characteristics of subjects, teachers, school conditions, and the community; (3) Providing opportunities for teachers to share information and experiences about the curriculum, as well as to develop technology and technology; (4) The lessons given to teachers to convey their opinions at MGMP status meetings enhance their abilities; (5) Building collaboration with other institutions for a conducive, effective and fun teaching and learning process".

One of these objectives includes providing opportunities for teachers to develop science and technology. This goal will be achieved if the teachers are skilled and accustomed to using technology product applications and are able to improve and develop themselves through various activities that are able to support these abilities. One of the activities carried out was participating in self-development activities through the Community Partnership Program (PKM) with LPTKs such as Pasundan University.

In the industrial revolution era 4.0, nowadays, it has entered the online world, the internet has mastered life, but it can have an impact (+) or (-), so the extent to which educators adopt the technology to do good and useful for the general public and students especially. One of the positive internets uses is online learning through e-learning.

In addition, the publication of scientific papers has entered the online system. For publication, of course, there must be scientific articles from the results of the research. However, some teachers rarely conduct research because of difficulties in data processing. Of these problems, e-learning learning and data processing were felt by some teachers to be difficult.

Based on the results of a survey of high school mathematics teachers in Bandung City and District, the results showed that some teachers did not know SPSS which was useful in research, understanding some teachers in collecting data according to the research problem formulation was lacking, some teachers did not know e-learning applications that use video conference.

Whereas according to the computer vehicle in collaboration with Andi $(2010$, p. 2), "SPSS is a statistical data processing software with easy usage. So it is a pity if the teachers do not utilize SPSS for research. In addition, e-learning that uses video conference (vicon) is very useful, because with the help of the internet through Vicon we can learn anywhere and anytime without knowing the limitations of distance and time.

This is consistent with the fact that learning that utilizes ICT is in line with the 2013 curriculum that is being implemented in Indonesia today. Technology is utilized for the effectiveness and efficiency of the learning process, and research so as to encourage teachers to develop learning and carry out research. Therefore tridharma namely education and research can be done with the many teachers who do this. Thus the Community Partnership Program is a program to assist teachers in implementing the 2013 curriculum, namely the application of ICT in learning and research

\section{Methods}

The target and outcome of the implementation of the Community Partnership Program are that teachers can collect data for research and apply e-learning in the learning process. The method used to overcome these problems is by providing training or training, guidance, and mentoring to the teachers.

Training is carried out by meeting face-to-face with teachers. This meeting was held with the aim to provide understanding and skills of the teachers in collecting research data and using e-learning applications using vicon.

After the training, continued with guidance and assistance. Guidance and mentoring is done through the website with mathematical link.fkip.unpas.ac.id, and using e-learning applications via video conference with Zoom. On its website https://zoom.us, Zoom is the leader in modern enterprise video communications, with an easy, reliable cloud platform for video and audio conferencing, chat, and webinars. Training, guidance and mentoring activities are carried out through 3 steps.

First, training, mentoring and mentoring in using SPSS features. The desired outcome is that teachers understand, master, and are skilled in inputting data according to the type or scale of the data.

Second, training, mentoring and mentoring in collecting data according to the formulation of research problems. The desired outcome of this activity is that teachers understand, master, and are skilled in making research instruments. 
Third, training in using e-learning applications. This training activity includes an explanation of the use of the video conference e-learning application, Zoom. The desired output is that the teachers can discuss the results of data collection through video conferencing.

In order to achieve the solution and target output, the SPSS application and vicon (Zoom) are needed as some finished products that will be implemented in PKM. Huda (2017), explained in his writing that "In 1968, Norman H. Nie, C. Hadlai (Tex) Hull and Dale H. Bent, three young men from different professional backgrounds, developed a fine-tuning system based on statistical ideas to use for turning raw data (RAW) into essential information for making decisions. This revolutionary statistical software system is called SPSS, which became a Statistical Package for Social Sciences. But along with the increasing benefits of SPSS in various commercial public sectors, and academic organizations such as social and sins, the need for SPSS is now used for various scientific fields, especially in this PKM.

This e-learning application through Zoom can be used in 3 ways, namely: 1) Through the Web with a link: https://zoom.us, 2) Through the install process by downloading the master/ application and installed on the PC, 3) Via smartphone the application can be downloaded from the Playstore. With the various ways to use this vicon, it will certainly make it easy for teachers to quickly and easily access elearning through the vicon

\section{Results and Discussion}

Community Partnership Program (PKM) High School Teachers in the City and Regency of Bandung were attended by 14 Mathematics Teachers from the Bandung City MGMP, and 17 Mathematics Teachers from the Bandung Regency MGMP. This training activity was conducted on May 30, 2018, guidance and mentoring was carried out from the beginning of June to mid-August 2018.

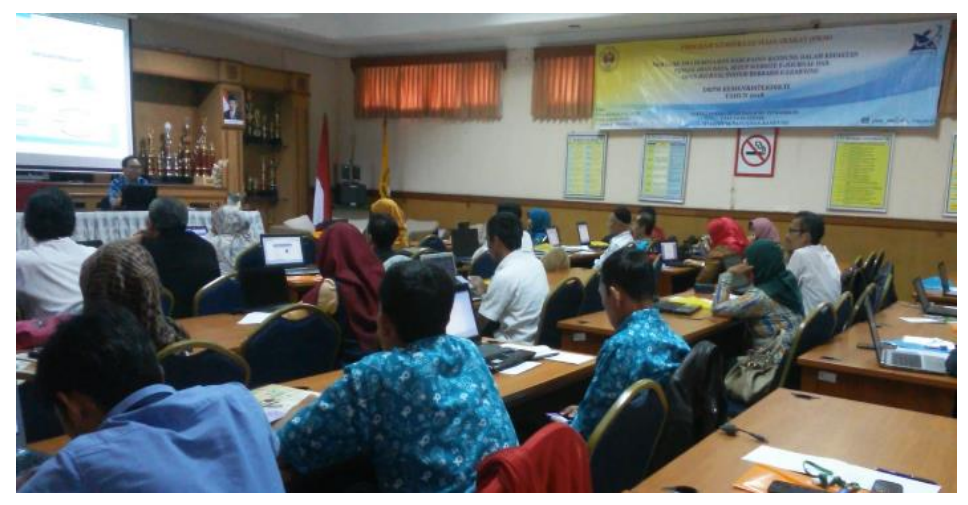

Figure 1. Training using SPSS features, and collecting data accordingly formulation of research problems

Training in using SPSS features and training in collecting data according to the formulation of research problems was presented by Mr. Thesa Kandaga, S.Si., M.Pd. During the training, many teachers asked questions about the research, they felt motivated by this training. There were representatives of teachers from the two MGMPs who expressed their opinion that they were getting the first time training like this.

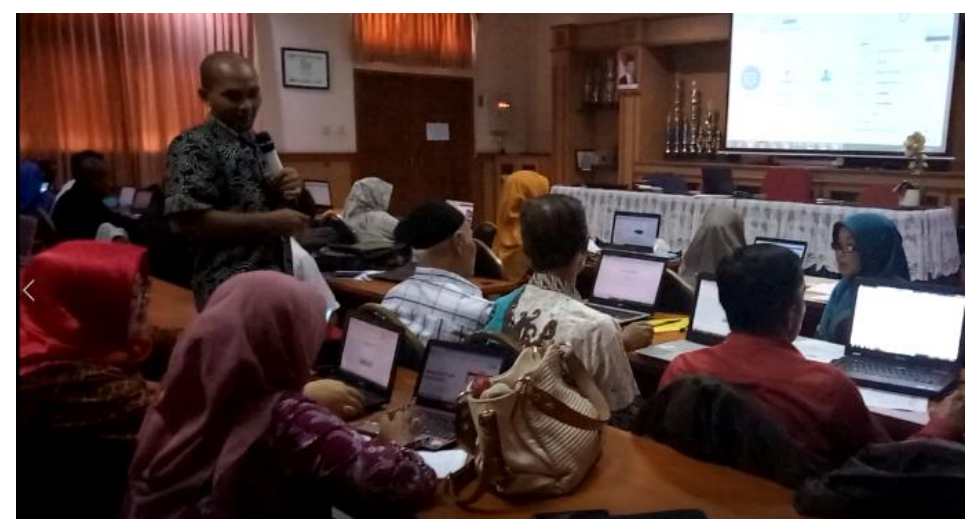

Figure 2. Training of e-learning applications 
Training in using e-learning applications was delivered by Mr. Ali Imron S.T. who is an instructor from the South East ASEAN Ministry of Open and Learning Center (SEAMOLEC). "SEAMOLEC is an institution established by the Minister of Education in Southeast Asia in 1997", (Ariefyanto, 2013). Therefore, we invite instructors from SEAMOLEC that learning through Distance Education (PJJ) can be applied in the teaching and learning process by teachers to students in general and in PKM activities in particular, especially for mentoring and mentoring teachers, so that our learning process can be done at any time and anywhere without the limitations of distance and time.

One of the PJJs delivered in PKM training is e-learning through Zoom. This zoom will later be used by us in the process of guidance and mentoring. The speaker gives an explanation of the theory and practice of how to use the application so that the teacher can immediately implement how to use the application.

Counseling and mentoring contains the delivery of the material that has been delivered during the training to remind the material that has been submitted that is poured through the web, besides that we also update or add the latest material that we share via the web, then there we also give assignments with help there instructions and steps on how to do it.

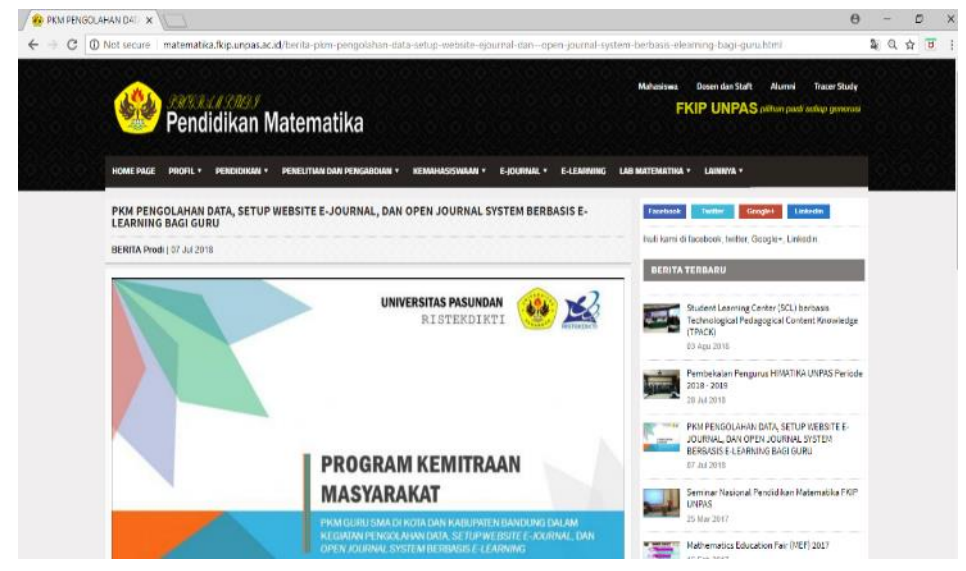

Figure 3. Guidance and Assistance Through the Web

The task was collected through e-mail pkm_math@unpas.ac.id, after which participants will present their assignments via video conference. Through vicon, the teachers will be guided and assisted when they find tasks that are considered wrong so that their tasks can be repaired and no longer do the same mistakes.

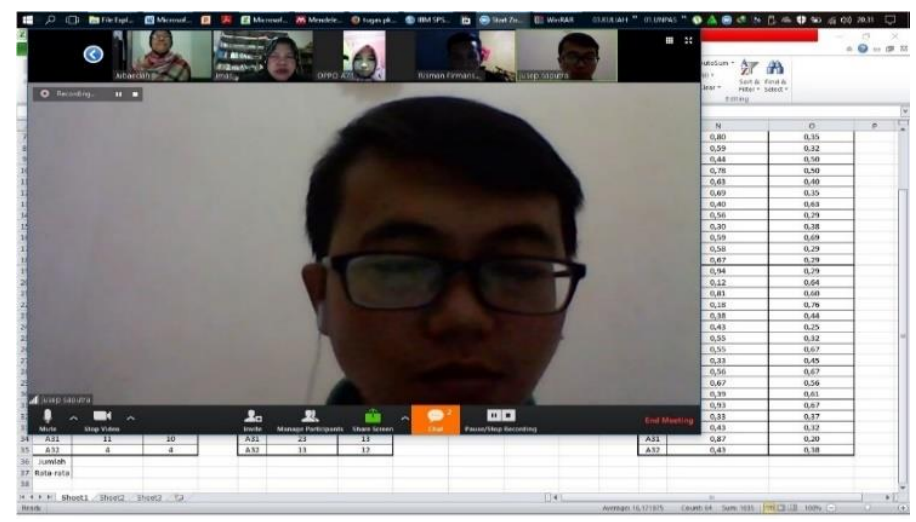

Figure 4. Guidance and Assistance Through Video Conference

After conducting PKM activities in using SPSS features, collecting data according to the formulation of research problems, and using e-learning applications, we gave a questionnaire on the quality of PKM implementation and self-test questionnaire, to measure participants' abilities after participating in activities, we also made observations towards the ICT capabilities of teachers. The 
following is a bar diagram of the quality of the PKM to facilitate readers in assessing the quality of the training that has been held in Figure 5.

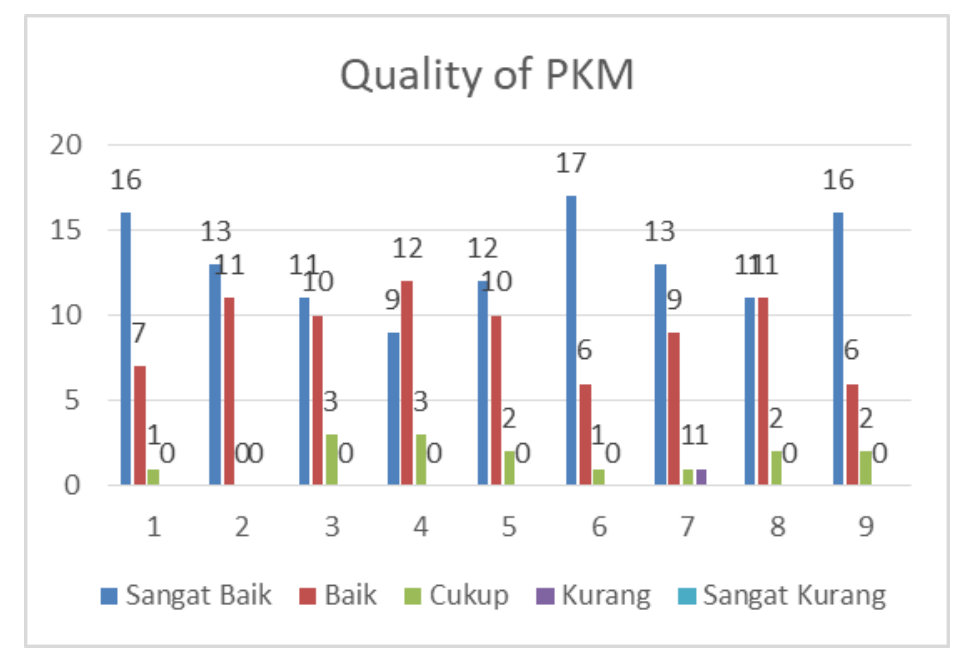

Figure 5. Quality of PKM

Figure 5 consists of 9 statements, namely (1) The purpose of this PKM is very helpful, (2) The material from this PKM can support my profession, (3) The training material is well presented, (4) The time for the implementation of this PKM is effectively presented and efficient, (5) The method used in the presentation of the material is good, (6) The speaker is brought by a competent person in his field, (7) The place for the implementation of the PKM supports the continuity of the event well, (8) The tools and media used in this PKM support good delivery of material, (9) The service of the PKM committee to the participants is good.

Figure 5 describes that visually seen through a bar chart illustrates that almost all the statements of the teachers stated that the quality of PKM was Very Good, so overall the teachers considered very well the PKM activities. The following is also a bar diagram about the quality of the self-test, to facilitate the reader in reading the ability of participants through the bar diagram in Figure 6.

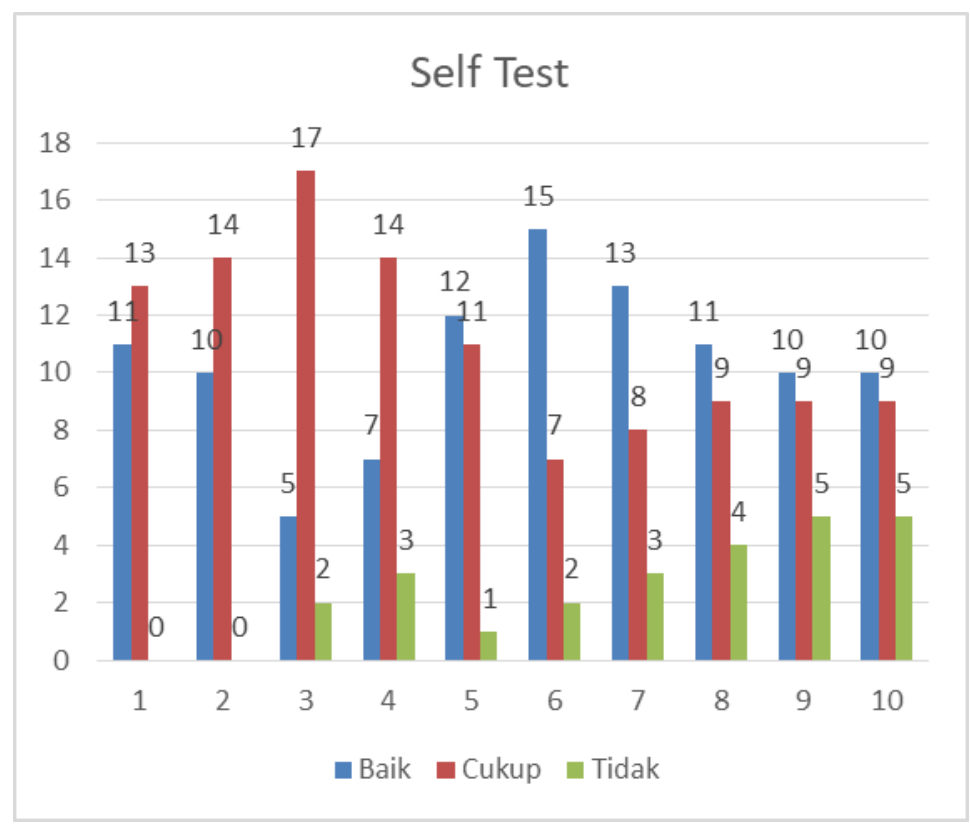

Figure 6. Self-test of Teacher Ability

Figure 6 consists of 10 statements, namely (1) Understanding the appropriate research problem formulation techniques, (2) Understanding test instrument design techniques, (3) Making problem formulations that are in accordance with the planned research topic, (4) Making research instruments 
that in accordance with the planned research topics, (5) Using computers in statistical data processing, (6) Knowing the usefulness of SPSS, (7) Being able to input data into SPSS, (8) Installing video conference applications on laptop or mobile devices, (9) Using WebEx / Zoom for direct communication via images, sound or camera / video, (10) Knowing the features of WebEx / Zoom.

Statement (1) to (4) to measure ability in understanding, mastering, and skilled in making research instruments. The results of filling out the questionnaire for the four statements were obtained that the teachers stated their abilities were good enough, in understanding, mastering, and skilled in making research instruments in the category of good enough.

Statement (5) to (7) to measure the ability to understand, master, and be skilled in inputting data according to the type or scale of the data. The results of filling out the questionnaire for the three statements obtained that the ability is good in inputting data according to the type or scale of the data.

Statement (8) to (10) to measure the ability of teachers to use video conferencing to get guidance and assistance in carrying out tasks. The results of the questionnaire analysis for the three statements obtained that the ability is good at using video conferencing to get guidance and assistance in doing assignments.

In PKM the next meeting will be holding training, mentoring, and assistance in processing research data with SPSS; training, mentoring, and mentoring in analyzing, and interpreting research research data; training, mentoring, and mentoring in making scientific articles; set up training for e-journal website, submission of e-ISSN, and DOI; and training, mentoring, and mentoring in using OJS for publication of scientific articles and others

\section{Conclusions}

Based on the analysis, the results of the discussions that have been analyzed in the previous description, concluded that (1) the quality of PKM in formulating problems, testing instruments, using SPSS features, and video conferencing was very good, (2) Teacher's ability in understanding, mastering, and skilled in making research instruments either test or non-test is in a good enough category, (3) The ability of teachers to input data according to type or scale of data is in good category, (4) Teacher's ability to use video conferencing to get guidance and mentoring in doing assignments are in good category

\section{Reference}

Andi. (2010). Mengolah Data Statistik Hasil Penelitian dengan SPSS 17.0.: Semarang: Wahana Komputer.

Ariefyanto, M. I. (2013). Ini Model Pendidikan Jarak Jauh di Indonesia. https://www.republika.co.id/berita/pendidikan/eduaction/13/03/19/mjvwxj-ini-modelpendidikan-jarak-jauh-di-indonesia. 19 Maret 2013.

Mangindaan, E. E. (2009). Peraturan Menteri Negara Pendayagunaan Aparatur Negara Dan Reformasi Birokrasi Nomor 16 Tahun 2009 Tentang Jabatan Fungsional Guru dan Angka Kreditnya. Jakarta: Menteri Negara Pendayagunaan Aparatur Negara dan Reformasi Birokrasi Republik Indonesia.. 